378.147::811.163.41(497.7)

https://doi.org/10.18485/kij.2021.68.2.8

\author{
АНА Д. НОВАКОВИЪ \\ Универзитет „Св. Кирил и Методиј” - Скопље \\ Филолошки факултет „Блаже Конески”
}

Оригинални научни рад

Примљен: 29.09.2021.

Прихваћен: 15.11.2021.

\title{
СТАТУС СРПСКОГ ЈЕЗИКА НА ФИЛОЛОШКОМ ФАКУЛТЕТУ „БЛАЖЕ КОНЕСКИ” УНИВЕРЗИТЕТА „СВ. КИРИЛ И МЕТОДИЈ” У СКОПљУ
}

\begin{abstract}
Рад даје увид у историјат високошколске наставе српског језика и књижевности у данашњој Републици Северној Македонији, почевши од формирања Филозофског факултета у Скопљу као првог огранка Универзитета у Београду, а с посебним освртом на период од школске 2014/15. године до данас. На крају рада дају се могућа решења проблема и препрека с којима се суочава наставник српског језика на Филолошком факултету „Блаже Конески” у Скопљу, као и могућа решења за унапређење ове наставе. Напослетку, истиче се потреба за унапређивањем сарадње међу надлежним установама како би се очувала настава српског језика на Филолошком факултету у Скопљу, те долази се до закључка да би се подршком наставе, наставника и студената допринело очувању и неговању српског језика, књижевности и културе на територији македонске државе.
\end{abstract}

Кључне речи: српски језик и књижевност, настава српског језика, високошколска настава, Филолошки факултет „Блаже Конески”, Република Северна Македонија.

\section{1. Увод}

1.1. О актуелном стању наставе и изучавању српског језика и књижевности на свим нивоима образовања у региону и свету пишу бројни аутори у чијим радовима се наглашава потреба да неко не само чује, већ и саслуша све проблеме српских лектората и да коначно увиди колико је потребно реаговати и спасити оно што је преостало и што се спасити може у вези са наставом српског језика, књижевности и културе. ${ }^{1}$ Ово се посебно односи на стање наставе српског је-

*ananovakovic93@yahoo.com

${ }^{1} \mathrm{O}$ увиду у стање и заступљеност српског језика и књижевности на високошколским установама, проблемима са којима се сусрећу тамошњи лектори, наставници и професори, као и о могућим решењима актуелних проблема види више у: Цидилко (2011), Пожгај Хаџи и Балажић (2011), 
зика и књижевности након свих друштвено-политичких околности и преокрета новијег доба проузроковани распадом социјалистичке Југославије и поделе југословенског становништва путем повлачења административних граница. Стога, распад заједничке југословенске државе можемо довести у везу са следећим околностима које су пак довеле до поражавајућег стања наставе српског језика и књижевности: једна се односи на пад интереса за проучавање српскохрватског ${ }^{2}$ језика на универзитетима у Европи и свету и на формирање издвојених лектората за хрватски језик на штету српског језика; док друга околност односи се на појаву друштвеног феномена који се карактерише жељом и потребом бивших југословенских држава и народа да створе (кодификују) „свој” језик из једног истог дотадашњег српскохрватског који ће се именовати према нацији, а не према лингвистичким чињеницама и научним основама (хрватски, босански, а од скорије и црногорски језик), што је пак на европским и другим светским универзитетима довело до формирања нових студијских програма, пре свега оних под називом БХС студије с циљем стицања преводилачких вештина из „три новопостојећа језика”. Ова подела једног језика на четири „различита” и увођење и формирање нових студијских програма за сваки језик посебно догодило се и на универзитетима бивших југословенских република. Сходно томе, данас се суочавамо са одумирањем високошколске наставе српског језика и књижевности у оквиру многих универзитета, као и одумирањем наставе на српском језику на свим нивоима образовања изван Србије, укључујући основне и средње школе и високобразовне установе.

1.2. Полазиште нашег рада су управо све поменуте чињенице које су нарочито у државама региона и бившим југословенским републикама где је настањено српско аутохтоно становништво проузроковале постепено нестајање или порицање српске етно-лингвистичке заједнице и нестајање или порицање србистике у образовном систему већине држава (на пример: у европејским државама - Румунија, Мађарска, Бугарска, Словенија, Хрватска - или у Албанији, Босни и Херцеговини и др.). Будући да се међу поменутим земљама у којима су српска етно-лингвистичка заједница и србистика такође слабиле под утицајем нових политичко-друштвених околности налази и Република (од недавно Северна) Македонија, циљ нашег рада је да прикажемо развој србистике на високошколском нивоу у македонској држави, почевши од формирања Филозофског факултета у Скопљу као првог огранка Универзитета у Београду, с посебним освртом на наставу и проблеме србистике ${ }^{3}$ од школске 2014/15. године до данас, а са жељом да укажемо на потешкоће с којима се сусреће тамошњи лектор/наставник/професор заједно са студентима и да понудимо могућа решења истих

Карасињски и Савицка (2011), Јелић-Кубуриду (2011) Ђорђевић (2014), Радан (2014), Супрунчук и Леонова (2015), Росић (2016), Керкез (2016), Тод и Зорић (2018), Степанов (2019) и други.

${ }^{2}$ Термином српскохрватски језик је све до распада Југославије именован језик који је био заједнички за четири југословенске републике: Србија, Хрватска, Босна и Херцеговина и Црна Гора.

${ }^{3}$ У доба формирања скопског Филозофског факултета у званичној употреби био је назив сербокроатистика/југославистика. 
како би се настава српског језика и књижевности данас на Филолошком факултету „Блаже Конески” у Скопљу унапредила и даље развијала, али пре свега очувала.

\section{2. Почеци и развој високошколске наставе српског језика у Македонији}

2.1. Ситуацијом, стањем и проблемима српске етно-лингвистичке заједнице, стањем и проблемима наставе српског језика и књижевности и наставе на српском језику у некадашњој федеративној, а данас суседној држави Македонији бавили су се следећи аутори: Станковић (2001, 2004 и 2018), Вујадиновић (2001, 2002 и 2010), Радић (2003), Вељковић (2005), Бошњаковић и Станковић (2007), Новаковић (2020) и др. Историографске чињенице указују на вишевековну присутност српског становништва на територији Македоније, а самим тим и на подужу историју употребе српског језика и постојања српских школа у којима се изучавао српски језик и књижевност. Нажалост, у вези са стањем основношколске и средњошколске наставе српског језика и књижевности и наставе на српском језику у македонској држави данас се не може ништа позитивно рећи. ${ }^{4}$ У вези са српским етничким и лингвистичким питањем „остављајући по страни српско средњовековље у Македонији, можемо констатовати да је садашње српско питање у Македонији у најтешњој вези са крупним политичким догађајима који су се на Балкану одвијали у XIX и XX веку” (Радић 2003: 228). Тако, опадање броја српског становништва и постепено нестајање наставе српског језика и књижевности на свим нивоима образовања с једне стране резултат је политике која се око тридесет година спроводи у овој земљи. С друге стране, треба имати у виду и околности до којих је довео распад СФРЈ и чињеницу да разлоге за пад броја становника који се осећају као припадници српске етничке заједнице, односно њихово поистовећивање са македонским народом „треба тражити у сродној језичкој, и у истој конфесионалној припадности, као и у условима заједничког живљења" (Станковић 2004: 46).

2.2. Будући да се у научним и академским круговима тек последњих неколико година озбиљније говори о проблемима у високошколској настави српског језика у Македонији и предлажу се стратегије за њено очување и унапређење (уп. Станковић 2018), у овом раду желели смо да прикажемо развој србистике на Универзитету у Скопљу и да се задржимо на актуелно стање и проблеме поменуте наставе чије је очување и унапређење од изузетног значаја за будућност

${ }^{4} \mathrm{O}$ српском језику и књижевности у основним (и средњим) школама и школама са наставом на српском језику више сазнајемо у Бошњаковић и Станковић (2007), Вујадиновић (2002 и 2010), Новаковић (2020). Додатно сазнајемо и следеће: „у другој половини двадесетог столећа српска лингвистика организовано нимало се није бавила нашим језиком на подручју данашње Македоније” (Станковић 2001: 51), а „о етничким Србима и њиховим институцијама у некада братској, а сада суседној држави, Србија није нимало бринула, нити су, пак, довољно бриге о њима и њиховом културном наслеђу показивале српске националне установе" (Станковић 2004: 46). 
целокупне српске етно-лингвистичке заједнице на јужним балканским просторима, имајући у виду то да „у свакој организованој држави, са дефинисаном и утврђеном националном политиком, у домену бриге о националном и културном идентитету питању језика припада место од највећег значаја" (Танасић 2014: 47-48). Шта смо имали, шта смо изгубили и куда нас је све то довело, образложићемо у даљем тексту овога рада.

2.3. Године 1913. пробудила се идеја о оснивању високошколске установе у Македонији када је тадашњи „министар просвете Љуба Јовановић предложио влади Краљевине Србије оснивање Филозофског факултета у Скопљу” (Јовановић 2011: 23). Иако је избијање Првог светског рата спречило спровођење ове идеје, након формирања југословенске државе „у писму актуелног министра просвете Павла Маринковића тадашњем ректору Београдског универзитета Јовану Цвијићу из 1919. стоји да би оснивање скопског факултета, поред великог националног и културног значаја и утицаја, у доброј мери растеретило рад универзитета у Београду" (Јовановић 2011: 23). Тадашња имена која су сачињавала наставни кадар и научну академску елиту значила су озбиљност и важност скопског факулета, који је неколико година касније, указом од 2. фебруара 1920. године, основан под називом Филозофски факултет а који се управљао према законима и уредбама Београдског универзитета. ${ }^{5}$

2.4. Први декан новоформираног факултета био је Тихомир Остојић, први наставници били су Тихомир Остојић (српска и југословенска књижевност), Степан Михајлович Куљбакин (словенска филологија), Радослав Грујић (историја српског народа), Мита Костић (српска историја), Грга Новак (историја Средњег века), Милош Ивковић (српски језик), Петар Михајловић Бицили (историја старог и средњег века) и други, а предавало се на десет катедри међу којима и Катедра за југословенску књижевност. С поносом се може рећи да „највећи интерес скопских студената владао је за српскохрватски језик и југословенску књижевност, док се посебно атрактивном показала група за педагогију” (Јовановић 2011: 26, такође в. у: Сто година Филозофског факултета, 2020: 51). Формирање Филозофског факултета подстакло је и формирање више друштава и установа који су такође били значајни за очување и неговање српског културног наслеђа и идентитета, језика, књижевности и културе на територији данашњег јужног суседа (нпр. Скопско научно друштво, Академско певачко друштво Обилић, Друштво студената Његош, Кружок напредних студената, Друштво за српски језик и књижевност, Педагошко друштво, Музеј Јужне Србије, Ге-

${ }^{5} \mathrm{C}$ тим у вези, поводом стогодишњице скопског Филозофског факултета актуелни руководиоци и представници високошколске установе приредили су обележавање јубилеја и говорили о историји факултета од његовог оснивања до данас: „наставата започнала со само 35 студенти на историја, филозофија, педагогија, лингвистика и книжевност, со наставници кои биле составени од тогашната научна и културна елита" (в. у: Сто година Филозофског факултета 2020: 9).

* Српске власти и научни кругови, надлежне установе и министарства, Београдски универзитет и актуелни наставници српског језика на Филолошком факултету „Блаже Конески” нису присуствовали обележавању стогодишњице формирања Филозофског факултета као први огранак Београдског универзитета! 
ографско друштво итд.). Такође, „Министарство просвете је награђивало тзв. светосавске темате које су писали скопски студенти, најчешће из области националне историје, филологије и етнографије. [...] Наиме, октобра 1927. главни одбор Друштва Светог Саве је одлучио да се сваке године најуспешнији студент факултета награди златним прстеном” (Јовановић 2011: 30). Скопски студенти су имали прилику бити носиоци и државне стипендије чији је циљ био промовисање српскохрватског језика. ${ }^{6}$ Од 1941. године „после мартовских демонстрација [...] ректорат Београдског универзитета је донео уредбу о престанку рада Филозофског факултета у Скопљу, до чега је и дошло 3. априла 1941. године" (Јовановић 2011: 39). У даљем периоду бугарске окупаторске власти почеле су да отварају бугарске школе и свој универзитет у Скопљу у којима се настава спроводила све до њене капитулације и краја Другог светког рата, а већ 1946. године стари наставни кадар се вратио у учионице Филозофског факултета социјалистичке Македоније.

2.5. Након испитивања услова за оснивање Универзитета у Скопљу, надлежна Комисија је предлогом упућеним Министартву просвете званично затражила и остваривање те идеје. Прва високообразовна институција био је свакако Филозофски факултет са два одсека: историјско-филолошки и природно-математички. ${ }^{7}$ Поред домаћих, у настави били су ангажовани и хонорарни наставници и предавачи са других југословенских универзитета, а развој науке и научних области, као и све већи број студената седамдесетих година довели су до пораста студијских група из области друштвених и хуманистичких наука, па су се, сасвим очекивано, 1974. године филолошке наставне групе издвојиле у „посебен Филолошки факултет” (Сто година Филозофског факултета 2020: 84).

2.6. Наиме, „првих деценија живота у социјалистичкој 'братској' заједници, српско национално питање у Македонији није могло имати посебну тежину, осим што се нова политичка ситуација одразила на обим и статус српског становништва, односно на очување и неговање националног идентитета" (Радић 2003: 238-239), што је пак у каснијим деценијама заједничког живљења довело до постепеног поистовећивања значајног броја припадника српске етничке заједнице са Македонцима, махом проузроковано недостатком довољно јаке и потребне подршке српској заједници и од стране македонске домаћинске земље и од стране матице Србије. ${ }^{8}$ Сходно томе већ шездесетих година прошлог века настава на српском језику је почела да губи свој статус, а све чешће се догађало

${ }^{6}$ „Декан Колендић је сугерисао Министарству просвете да се при одређивању питомаца за државну стипендију узимају у обзир и студенти 9. групе, под условом да им српскохрватски језик буде први предмет” (Јовановић 2011: 29).

${ }^{7}$, „Од 1 до 5 септември 1946 година заинтересираните идни студенти можеле да се пријават на Филозофскиот факултет. Првите предавања биле одржани на 16. декември 1946 година. Факултетот официјално започнал со работа на 29. ноември 1946 г.” (в. Сто година Филозофског факултета 2020: 72 ).

${ }^{8}$ „Овом процесу допринели су и интензивна асимилација становништва и перманентна небрига матичне државе за њихов положај. Апстрактна национална политика Србије условила је да се током њене социјалистичке прошлости потпуно занемари положај сународника у суседним земљама" (Башић 2004: 675). 
да се она угаси у великом броју основних и средњих школа (в. Новаковић, 2020: 313) што је пак сасвим логично, утицало и на статус наставе српског језика и књижевности на високошколском нивоу у савезној Републици Македонији. У вези са слабљењем политичке, културне и просветне сарадње између социјалистичке Македоније и социјалистичке Србије аутор П. Радић (2003: 242), примера ради, упоређује статус српског језика као наставни предмет на Филолошком факултету у Скопљу и статус македонског језика на Филолошком факултету у Београду.

2.7. Српски језик и књижевност у оквиру скопског Филолошког факултета од социјалистичке Македоније до данашње суверене аутономне државе предају се на Катедри за македонски језик и јужнословенске језике и на Катедри за македонску књижевност и јужнословенске књижевности‥ Први наставници Катедре за македонски језик и јужнословенске језике били су, поред оснивача и управника катедре Блажета Конеског, и Васо Томановић, Крум Тошев, Радмила Угринова-Скаловска и Божидар Видоески. Седамдесетих и осамдесетих година Факултет проширује свој наставни кадар, а међу професорима који су предавали српски језик у најширем смислу лингвистичке дисциплине на овој катедри били су: Васо Томановић, Видосава Павловска, Божидар Видоески, Вера Сибиновић, Станислав Станковић, Љубиша Станковић, Чедомир Стојменовић и Ненад Вујадиновић. С друге стране, као што је већ било поменуто, на Филолошком факултету на Катедри за македонску књижевност и јужнословенске књижевности заступљени су и предмети из области српске књижевности које су својевремено предавали Димче Левков, Миодраг Друговац, Георги Сталев, Виолета Пирузе Тасевска, Науме Радически, Нина Атанасова Шкрињарић и Трајче Стамески.

2.8. Увођењем тзв. „болоње” и новог система студирања, Филолошки факултет у Скопљу је своје студије прилагођавао његовим потребама и потребама тржишта рада. Неке групе и смерови су се угасили, али су зато формиране нове студијске групе према акредитованим студијским програмима, па чак и катедре, као што је, на пример, Катедра за превођење и тумачење. Од школске 2008/2009. године основане су студијске групе за српски, словеначки и хрватски језик на које се студенти могу уписивати наизменично сваке четврте године (в. http:// flf.ukim.mk/katedri-stud-grupi/mak-jazik-juznoslov-jazici/). ${ }^{10}$ Новонастала ситуација након распада Југославије да „неки универзитети задржавају лекторате српскохрватског, други се преоријентишу на хрватски језик, трећи на српски, а током времена велики број универзитета се одлучује на 'компромисно рјешење'

\footnotetext{
${ }^{9}$ Катедра за македонски језик и јужнословенске језике формирана је у оквиру Филозофског факултета још 1946. године под називом Катедра за јужнословенски јазици. Први управник и оснивач њене наследнице - Катедра за македонски јазик и јужнословенски јазици био је Блаже Конески.

${ }^{10}$ Српске политичке странке у Македонији и други македонски политички парламентарни представници воле да кажу да је овим путем формирана Катедра за српски језик (често без књижевности). Ту „катедру” односно студијску групу нико до сада није истински подржао нити пак представљао, као што није подржао сада већ несталу наставу на српском језику у средњим школама, а не подржава ни актуелну наставу на српском језику у основним школама која је у врло лошем стању.
} 
и успоставља нову језичку творевину - босанско-хрватско-српски (БХС) језик” (Крајишник 2014: 219) у Македонији довела је до сасвим другачијег стања у високошколској настави, где се у оквирима посебних студијских програма предају и српски и хрватски језик - први препуштен својој судбини и судбини тамошњих наставника, а други добро организован у облику лектората са званичним руководиоцем студијског програма, редовног професора Филолошког факултета Људмила Спасова ${ }^{11}$.

\section{3. Настава српског језика на Филолошком факултету „Блаже Конески” од 2014/15. године до данас}

3.1. Од 2008. до 2014. године настава српског језика на Филолошком факултету „Блаже Конески” Универзитета у Скопљу спроводила се према новом акредитованом студијском програму из 2008. и 2013. године као први главни предмет, као други главни предмет (изборни модул) и као изборни предмет са факултетске и универзитетске листе.

3.2. Студијски програм за Српски језик и књижевност (односно осмосеместралне студије српског језика и књижевности као главни предмет чији обим износи укупно 240 ЕСПБ-а) последњи пут је акредитован 2013. године. Према овом студијском програму, у трећем семестру студија, студент се опредељује за један од понуђених смерова и у зависности од тога он може након дипломирања стећи звање: 1) дипломирани филолог српског језика и књижевности; 2) дипломирани професор српског језика и књижевности и 3) дипломирани са српским језиком. Такође, студенти матичне, али и других катедри, имају могућност да упишу шестосеместралне студије из области српског језика као други изборни модул у обиму од 60 ЕСПБ-а, а студенту се након дипломирања и последњег положеног испита изборног модула додељује посебни сертификат уз стечену диплому о завршеном другом изборном модулу, односно уверење о доквалификацији из области српског језика. Напослетку, српски језик се може изучавати и као изборни предмет који се налази на факултетској листи изборних прдмета за студенте свих студијских група Филолошког факултета и на тзв. УКИМ-листи, односно универзитетској листи, за студенте свих факултета државног универзитета „Св. Кирил и Методиј” у Скопљу. Српски језик као изборни предмет организован је у облику курса који се састоји од укупно четири предмета под називима Српски језик Ц1 (увод у историју и развој српског језика са фонетиком и фонологијом српског стандардног језика), Српски језик Ц2 (морфологија са творбом речи српског стандардног језика), Српски језик Цз (синтакса просте реченице српског стандардног језика) и Српски језик Ц4 (синтакса сложене реченице српског стандардног језика).

${ }^{11}$ „Хрвати су имали и свог координатора и наставника теоријске наставе проф. др Људмила Спасова и свог лектора. Наиме, одмах после распада СФРЈ и увођења овог програма Хрватска најредовније шаље своје лекторе, до сада их је сигурно било више од пет-шест у мандату од по неколико година!" (уп. Станковић, 2018). 
3.3. Након што су се редовни професори српског језика Чедомир Стојменовић и Љубиша Станковић пензионисали, на Филолошком факултету до 2014. године једини носилац србистичких предмета био је Ненад Вујадиновић. Већ „на почетку школске 2014/2015. године на Филолошком факултету 'Блаже Конески' у Скопљу у потпуности се осуо наставни кадар" (Станковић, 2018) јер je 2014. године, Ненад Вујадиновић, након годину дана одсуства, напустио свој професорски посао на Филолошком факултету у Скопљу. Ипак је настава српског језика на скопском факултету много раније почела да губи своју популарност и њено стање се сваке школске године све више погоршавало. Немајући апсолутно никакву институционалну или неку другу подршку, 2014. године одлазак јединог преосталог наставника предмета из области српског језика довео је високошколску наставу српског језика до руба пропасти, а тадашње уписане студенте на предметима из области србистике довео је до безнађа. Ово је, такође, многе идуће потенцијалне студенте србистике или србистичких предмета обесхрабрило да у новој академској години уписују и изучавају српски језик у оквиру својих основних студија, а у великој мери обесхрабрило је и идуће студенте да уписују основне студије из српског језика и књижевности као први, односно главни предмет. И овога пута су небрига надлежних институција и непостојање подршке настави српског језика, сасвим очекивано, статус србистике на Филолошком факултету довели скоро до безначајности. Будући да се србистика годинама није правилно и на одговарајући начин промовисала међу младима, онда није неочекивано и то што је наставник српског језика у таквим околностима немоћан да било шта у вези с тим промени. Тако је настава српског језика у Скопљу доспела до прага нестанка, а да о томе матица Србија и српске надлежне институције апсолутно ништа нису знале! ${ }^{12}$

3.4. Академске 2014/2015. године, након одласка Ненада Вујадиновића, схвативши озбиљност проблема и могућност гашења високошколске наставе српског језика на Филолошком факултету „Блаже Конески”, место наставникаволонтера и носиоца србистичких предмета прихватио је Станислав Станковић. А како је то било? Станислав Станковић је о лошем стању наставе српског језика на Филолошком факултету у Скопљу обавестио Амбасаду Републике Србије у Републици Македонији, те након обавештења надлежних министарстава и на сагласност Министарства иностраних послова Р. Србије и Министарства просвете, науке и технолошког развоја Р. Србије, амбасадорка Душанка Дивјак Томић је 2014. године потписала уговор са Филолошким факултетом и предло-

${ }^{12}$ „Тако се може десити да у неком славистичком центру буде изабран (ангажован) лектор за српски језик, а да за то не знају наше просветне власти. Може се десити да лекторат нестане, а да то ми не знамо, или да српски језик предаје некомпетентна и нестручна особа. Све то може имати несагледиве образовне и културне последице и тада се поставља питање чија је то одговорност и како то поправити. Чињеница је и то да тренутно лектори раде у различитим условима и да услови, по правилу, зависе од земље пријема. Различита је и снабдевеност наставним средствима и она се односи и на техничку опремљеност и на одговарајућу литературу” (Брборић 2018: 24). 
жила Станислава Станковића за лектора српског језика (в. Станковић, 2018). ${ }^{13}$ Од 2015. године до данас (има већ шест година) Станислав Станковић, и даље у истом непромењеном волонтерском статусу страног лектора за српски језик, путем договора са скопским Факултетом о ангажованошћу у настави (о томе в. више у Станковић, 2018), а уз помоћ и подршку ауторке овога рада (која је од 2018. године и званично ангажована у настави као сарадник из праксе - демонстратор), одржава у животу наставу српског језика на Филолошком факултету „Блаже Конески” уз повремене разговоре с надлежним институцијама о решавању проблема србистике у Скопљу. На самом почетку школске 2014/15. године од изузетне важности било је пружити подршку студентима који су већ били уписали студијски програм Српски језик и књижевност или неке од предмета из области србистике као други изборни модул или слободни изборни предмет, као и створити услове да студенти добију могућност да одслушају до краја већ започета предавања и полажу испите. Притом од изузетне важности била је и промоција србистичких предмета будући да је међу студентима и српским етно-лингвистичким круговима доспела информација да се настава српског језика угасила на Филолошком факултету након одласка професора Н. Вујадиновића. Од тада па све до данас, колико то услови наставе, услови факултета и могућности актуелних наставника дозвољавају, као и то какве (не)услове за унапређење наставе српског језика и у којој мери ствара национални став и институционална подршка, постоје могућности да нови студенти могу уписати само четворосеместрални изборни предмет Српски језик (Ц1, Ц2, Ц3 и Ц4).

\section{4. Студенти и проблеми наставе}

4.1. Упркос свим изазовима и проблемима, број студената на актуелним изборним предметима протеклих шест година је успео да одржи континуитет наставе српског језика. У табели у даљем тексту приказани су статистички подаци о броју уписаних студената ${ }^{14}$ :

\footnotetext{
${ }^{13}$ O томе С. Станковић (2018) саопштава: „Лично сам тада по препоруци конзула Љиљане Танасијевић у Скопљу разговарао са госпођом Јеленом Калезић из Министарства просвете у Београду. Све је остало на том једном разговору, и то телефонском... Амбасадорка ме је на почетку (2014) замолила да у све ово кренем као волонтер јер би тражење финансија из Београда пролонгирало добијање речене сагласности и казала да се касније мој статус мора институционализовати, тј. да ће се решити и финансијски део ове приче и тако, ево, све до данас..."

${ }^{14}$ Статистички подаци преузети су са сајта електронског индекса студената Филолошког факултета. Треба имати у виду да се у систему електронских индекаса студената не налазе студенти уписани по старом систему студирања, а понекад долази и до системских грешака, па се тако име и презиме неког од студената нађе и на листи сличног по називу предмета или неког другог предмета, те приказани број није коначан, већ приближан. Број студената у зимском семестру представља збир уписаних студената на предметима Српски језик Ц1 и Српски језик Ц3, а у летњем на предметима Српски језик Ц2 и Српски језик Ц4.
} 
Ана Д. Новаковић

\begin{tabular}{|l|c|c|}
\hline \multicolumn{1}{|c|}{ Школска година } & зимски семестар & летьи семестар \\
\hline $2015 / 16$. & 42 & 35 \\
\hline $2016 / 17$. & 34 & 17 \\
\hline $2017 / 18$. & 40 & 23 \\
\hline $2918 / 19$. & 32 & 15 \\
\hline $2019 / 20$. & 27 & 19 \\
\hline $2021 / 21$. & 26 & $11^{15}$ \\
\hline
\end{tabular}

4.2. Даља анализа података о уписаним студентима на изборним предметима из српског језика показала је и то да српски језик уписују најчешће студенти нематичне катедре или факултета. ${ }^{16}$ Из приказане табеле закључујемо да је просек уписаних студената на изборном предмету Српски језик у зимском семестру 34, а у летњем 20 студената. Разлог за опадање броја уписаних студената у летњим семестрима је то што главни предмети студентима не дозвољавају да одслушају четворосеместрални изборни курс до краја. Такође, студентима представља проблем и то што су ови предмети условљени положеним испитом из претходног по нивоу изборног предмета (на пример, студент не може уписати Српски језик Ц3, уколико није слушао предмете Српски језик Ц1 и Српски језик Ц2).

4.3. Један од највећих проблема предавача и високошколске наставе српског језика у Скопљу јесу одговарајућа наставна средства. Оно што је некада остало као наслеђе професора српског језика на скопском факултету и мала скромна библиотека у оквиру Кабинета је све што се може користити у настави српског језика. Осталу релевантну и потребну литературу, а посебно новију, предавачи најчешће траже на интернету. Такође, када је раније предмет, тј. студијски програм носио назив српскохрватски језик, у настави користили су се исти уџбеници, граматике, приручници и сви остали наставни материјали као и на другим југословенским универзитетима, а присутност и свакодневна употреба српскохрватског језика на целој територији бивше Југославије стварала је могућности за проучавање српскохрватског језика на нивоу матерњег, односно

\footnotetext{
${ }^{15}$ Овај број није коначан јер у време писања овог рада још увек је у току био упис у летњи семестар школске 2020/21. године, а често и након почетка семестра.

${ }^{16}$ Последњих шест година је само неколико студената са Катедре за македонски језик и јужнословенске језике или са Катедре за македонску књижевност и јужнословенске књижевности уписало српски језик као изборни јужнословенски језик. Остали наши студенти у највећем броју долазе са других катедри - највише са Катедре за превођење и тумачење, са Катедре за француски језик и књижевност, Катедре за италијански језик и књижевност, Катедре за шпански језик и књижевност, затим са Катедре за енглески језик и књижевност, Катедре за турски језик и књижевност (смер: турски као нематерњи језик), Катедре за славистику и Катедре за општу и компаративну књижевност, а повремено српски језик слушају и студенти са других факултета Универзитета „Св. Кирил и Методиј”.
} 
првог језика у Социјалистичкој Републици Македонији. Данас, не укључујући студенте којима је српски матерњи језик и добро владају њиме, млади у Македонији више нису у свакодневном контакту са српским језиком, не читају свакодневно текстове на српском језику, не слушају свакодневно српски језик у медијима, а још мање свакодневно говоре на српском језику. Стога, потребно је примењивати нове методолошке поступке путем којих ће македонски студенти изучавати српски језик као други језик или као страни језик. Иако, постоје поједини уџбеници и граматике српског језика као страног они су ипак намењени несловенском свету коме је српски језик у потпуности непознат. Блискост и сличност српског и македонског језика захтева сасвим нови приступ настави српског језика као страног намењен говорницима македонског језика, а што пак проузрокује потребу да се часови, односно предавања и вежбе, држе у новим, прилагођеним условима и то у различитим групама студената према одговарајућем нивоу познавања српског језика и потребама за његовим проучавањем (нпр. компаративистичко проучавање граматичке структуре језика, компаративистичко проучавање лексичке структуре језика, превођење са српског на македонски језик и обрнуто итд.)

\section{5. Уместо закључка}

5.1. За гашење лектората српског језика и за гашење наставе на српском језику због различитих проблема проузрокованим лошом језичком политиком и недостатком одговарајуће стратегије у вези са њом, како то аутор Пипер истиче „одговорни су, пре свега, министарства просвете и спољних послова, јер језичка политика мора да обухвата и бригу о статусу матичног језика у другим земљама" (Пипер 2014: 120). Али у свему томе одговорност је и наша, односно ми као заједница и као народ одговорни смо за велики број проблема насталих по питању културног наслеђа и језика.

5.2. Преглед историјата наставе српског језика на високошколском нивоу од оснивања Филозофског факултета у Скопљу па све до данас и актуелно стање високошколске наставе српског језика показује да је стање србистике на данашњем Филолошком факултету „Блаже Конески” Универзитета „Св. Кирил и Методиј” у Скопљу веома забрињавајуће. Почеци наставе сербокроатистике/ југославистике 1920. године под управом Београдског Универзитета везују се за велики интерес међу студенатима, да би од шездесетих година почела полако да губи свој статус све до 2015. године када након одласка и последњег наставника српског језика на Филолошком факултету у Скопљу скоро заувек нестала. Од 2015. године до данас, настава србистике на високошколском нивоу у Македонији постоји не зато што се о њој брину надлежне установе које то треба да раде, већ искључиво захваљујући актуелним наставницима. Данас се настава српског језика спроводи само као слободни изборни предмет који у оквиру својих редовних студија слушају најчешће студенти са нематичне катедре. 
5.3. Пошто формално-правно србистички наставни кадар на Филолошком факултету у Скопљу нема своје регулисано место, од изузетне је важности озваничити и утврдити статус бар једног редовног предавача. Уколико се даље тежи ка томе, а требало би, да се унапреди настава србистике и да се поред изборних предмета врати и настава српског језика као други и као први главни предмет, неопходн је ангажовати још једног наставника како би се створиле могућности за предавања из већег броја различитих србистичких предмета.

5.4. Проблеми које смо навели у раду у вези са очувањем, унапређењем и промовисањем наставе српског језка на високошколском нивоу морају се решити уз одговарајућу и снажну институционалну подршку. Пре свега, полазећи од чињенице да је српски живаљ вековима настањен на територији Републике Северне Македоније и да је његово основно људско право образовање на матерњем језику, деци припадника српске заједнице у Македонији треба омогућити образовање на српском језику и наставу српског језика на свим нивоима образовања. Иако се многи мање или више упућени баве језичком политиком српске заједнице на македонској територији, потребно је да се чује глас струке и да се реше проблеми са наставом на српском језику тако што ће се прво унапредити настава на високошколском нивоу, која би обучавала будући стручни наставнички кадар неопхдан Македонији да у будућности спроводи наставу српског језика и на српском језику у основним и средњим школама, а друго потребно је већ запослене учитеље и наставнике у основним (и професоре у средњим) школама додатно припремити и подстицати за рад у настави на српском језику, као и у настави факултативног предмета из српског језика и културе у основним (и средњим) школама. ${ }^{17}$

5.5. Да би се унапредила и даље развијала настава србистике на високошколском нивоу, потребна је подршка и сарадња надлежних институција (и српских и македонских). Такође, потребна је и комункација и сарадња на нивоу академске заједнице, међууниверзитетска сарадња скопског и београдског универзитета и потребна су адекватна наставна средства прилагођена македонским студентима. Додатни подстицај за унапређење наставе српског језика свакако допринело би и организовање различитих семинара, конференција, летњих школа и слично, који би били намењени и студентима и предавачима, те добро осмишљени план и стратегија са детаљно описаним поступцима у оквиру језичке политике и планирања који се морају што пре (још ове године!) спровести како би се настава српског језика и књижевности у Македонији очувала у будућности.

${ }^{17}$, „осадашња гледишта/сазнања компетентних аутора показују да наставници који предају у школама са наставом на српском језику у РМ углавном нису овладали ни стандардним српским језиком ни специјалним терминолошким регистрима из својих наставних области. [...] Потребно је организовање специјалних курсева српског језика за наставнике у школама са наставом на српском језику. Те курсеве генерално треба да организује и изводи страни лектор за српски језик при Филолошком факултету „Блаже Конески” у Скопљу” (према Станковић, 2018). 


\section{ЛИТЕРАТУРА}

Башић 2004: Г. Башић, Политичко-правни положај српске националне мањине у савременој југоисточној и централној Европи, Теме, Часопис за друштвене науке, бр. 2, Ниш: Универзитет у Нишу, 673-764.

Бошњаковић/Станковић 2007: Ж. Бошњаковић и С. Станковић, Српски као страни језик у Републици Македонији, у: М. Дешић (ур.), Српски као страни језик у теорији и пракси, Београд: Универзитет у Београду, Филолошки факултет, 319-324.

Брборић 2018: В. Брборић, Будућност лектората српског језика са освртом на прошлост и садашњост, $y$ : Д. Мршевић-Радовић и Б. Сувајџић (ур.), Научни састанак у Вукове дане, vol. 48, Београд: МСЦ и Филолошки факултет Универзитета у Београду, 21-30.

Вељковић 2005: Д. Вељковић, Положај српске мањине у Македонији, у: Војислав Становчић (ур.), Положај и идентитет српске мањине у југоситочној и цеентралној Европи, Зборник радова са научног скупа одржаног 26-29. новембра 2003. године, књ. 25, Београд: САНУ, Одељење друштвених наука, 153-159.

Вујадиновић 2001: Н. Вујадиновић, Настава на српском језику и српски језик као наставни предмет у Републици Македонији, Преглед данашњег стања, реферат са лингвистичке трибине: Српски језик у дијаспори, Београд: 28. новембар 2001, Институт за српски језик САНУ.

Вујадиновић 2002: Н. Вујадиновиќ, За некои проблеми во врска со наставата на српски јазик во основните училишта во Република Македонија, реферат са научног скупа, Охрид: 16-17. август 2002, Филолошки факултет „Блаже Конески" - Скопје.

Вујадиновић 2010: Н. Вујадиновиќ, Примена на искуствата од областа на огласувањето во решавањето на социолингвистички прашања (врз основа на еден конкретен пример), Скопје: Универзитет „Св. Кирил и Методиј”, Филолошки факултет „Блаже Конески”.

Ђорђевић 2014: В. Ђорђевић, Лекторат српског језика на Филозофском факултету Универзитета Коменски у Братислави, Наш језик, књ. XLV, св. 3-4, Београд: Институт за српски језик САНУ, 105-113.

Јелић-Кубуриду 2011: М. Јелић-Кубуриду, Српски језик у Грчкој, $y$ : В. Крајишник (ур.), Српски као страни у теорији и пракси II, Београд: Универзитет у Београду, Филолошки факултет, 305-312.

Јовановић 2011: В. Јовановић, „Просвета - најбржи творац нације”: Филозофски факултет у Скопљу 1920-1941, Токови историје, бр. 2, Београд: Институт за новију историју Србије, 23-41.

Керкез 2016: Д. Керкез, Србистика у Санкт Петербургу, y: В. Крајишник (ур.), Српски као страни у теорији и пракси III, Београд: Универзитет у Београду, Филолошки факултет, 437-442. 
Крајишник 2014: В. Крајишник, Лекторати српског језика, $y$ : С. Танасић (ур.), Зборник института за српски језик САНУ II, Српски језик и актуелна питања језичке политике, Београд: Српска академија наука и уметности, 217-226.

Красински/Савицка 2011: А. Красињски и И. Савицка, Српски језик на Универзитету Никола Коперник у Торуњу, у: В. Крајишник (ур.), Српски као страни у теорији и пракси II, Београд: Универзитет у Београду, Филолошки факултет, 217-228.

Новаковић 2020: А. Новаковиќ, Основне школе са наставом на српском језику у Републици Македонији данас, $y$ : В. Крајишник (ур.), Српски као страни језик у теорији и пракси IV, Београд: Универзитет у Београду, Филолошки факултет, 309-325.

Пипер 2014: П. Пипер, О стратегији језичке политике у Републици Србији, y: С. Танасић (ур.), Зборник института за српски језик САНУ II, Српски језик и актуелна питања језичке политике, Београд: Српска академија наука и уметности, 117-129.

Пожгај Хаџи/Балажић 2011: V. Požgaj Hadži i T. Balažić, Srpski u Sloveniji - Novo stoljeće, nove mogućnosti, y: В. Крајишник (ур.) Српски као страни y теорији и пракси II, Београд: Универзитет у Београду, Филолошки факултет, 205-216.

Радан 2014: М. Н. Радан, Школска и језичка ситуација код Срба у Румунији, у: С. Танасић (ур.), Зборник института за српски језик САНУ II, Српски језик и актуелна питања језичке политике, Београд: Српска академија наука и уметности, 197-215.

Радић 2003: П. Радић, Из историје српског питања у Македонији, културолошки аспект, Balcanica XXXII-XXXIII, Београд: Балканолошки институт САНУ, 227-252.

Росић 2016: M. Rosić, Status srpskog jezika kao stranog u Sjedinjenim Američkim Državama, у: В. Крајишник (ур.), Српски као страни у теорији и пракси III, Београд: Универзитет у Београду, Филолошки факултет, 421-424.

Станковић 2001: С. Станковић, Неколике напомене о Србима и српском језику у Републици Македонији (Из социолингвистичких прилика), Зборник Филолошког факултета Универзитета у Приштини, 11, 51-56.

Станковић 2004: С. Станковић, Македонци и македонски језик у Републици Србији - Pro et contra. y: Б. Сикимић (ур.), Скривене мањине на Балкану, Посебна издања 82. Београд: САНУ, Балканолошки институт, 41-49.

Станковић 2018: С. Станковић, Српски језик и књижевност на Универзитету „Св. Кирил и Методиј” у Скопљу, 48. међународни састанак слависта у Вукове дане, Београд-Тршић: Међународни славистички центар, Филолошки факултет Универзитета у Београду, 13-17. IX 2018. (саопштење).

Степанов 2019: С. Степанов, Српски језик на високошколским установама у Аустрији, Научни састанак слависта у Вукове дане, vol. 48, Београд: Филолошки факултет и МСЦ, 177-188. 
Сто година Филозофског факултета 2020: Р. Дуев (ур.), Филозофски факултет: еден век високо образование, еден век државотворност, Скопје: Филозофски факултет.

Супрунчук/Леонова 2015: М. Супрунчукк и Љ. Леонова, Преглед изучавања српског језика у Белорусији, Наш језик, књ. XLVI, св. 1-2, Београд: Институт за српски језик САНУ, 51-62.

Танасић 2014: С. Танасић, Значај научних институција за статус српског језика, y: С. Танасић (ур.), Зборник института за српски језик САНУ II, Српски језик и актуелна питања језичке политике, Београд: Српска академија наука и уметности, 47-60.

Тод/Зорић 2018: L. Todd и В. Зорић, Јужнословенски језици у Великој Британији у контексту кризе хуманистике - српски/хрватски језик на Универзитету у Нотингему, Научни састанак у Вукове дане, vol. 48, Београд: Филолошки факултет и МСЦ, 157-167.

Цидилко 2011: В. Цидилко, О концепту наставе српског језика и књижевности у Немачкој, y: В. Крајишник (ур.), Српски као страни у теорији и пракси II, Београд: Универзитет у Београду, Филолошки факултет, 197-204.

\section{Извори:}

Број уписаних студената - Iknow-систем: Студентски сервис Iknow (приступљено 3. 3. 2021).

Страница Филолошког факултета „Блаже Конески”: http:/fff.ukim.mk/ katedri-stud-grupi/mak-jazik-juznoslov-jazici/, приступљено 2. 3. 2021. године.

Студијски програм српког језика и књижевности 2013: Предлог-проект за усогласување на студиските програми од прв циклус студии на Филолошкиот факултет „Блаже Конески” со законот за високо образование, Скопје: Филолошки факултет „Блаже Конески” (https://flf.ukim.mk/katedri-stud-grupi/mak-jazikjuznoslov-jazici/, приступљено 3. 3. 2021). 
Ana D. Novaković

\title{
STATUS OF THE SERBIAN LANGUAGE AT THE FACULTY OF PHILOLOGY „BLAŽE KONESKI” IN SKOPJE
}

\begin{abstract}
Summary
This paper provides an insight into the history of the Serbian language and literature at the higher level education in today's Republic of N. Macedonia, starting with the establishment of the Faculty of Philosophy in Skopje being the very first branch of the University of Belgrade and including a special reference to teaching and its problems from 2014/15 school year up until this day. In conclusion, possible solutions to the problems that teachers have while teaching the Serbian language are also given, as well as possible solutions related to the improvement of the teaching itself. Finally, in order to preserve the teaching of the Serbian language at the Faculty of Philology in Skopje, the need to improve the cooperation among the competent institutions is emphasized and crucial. It is believed that given proper support to both teachers and students would do the best for the preservation and promotion of Serbian language, literature and culture in the Republic of N. Macedonia.
\end{abstract}

Key words: Serbian language and literature, Serbian language teaching, higher education, Faculty of Philology „Blaže Koneski”, Republic of N. Macedonia. 